\title{
Possibilities for Well Log Correlation using Standard Deviation Trends in Neogene-Quaternary Sediments, Sava Depression, Pannonian Basin
}

\author{
Marko Cvetković \\ University of Zagreb, Faculty of Mining, Geology and Petroleum Engineering, Zagreb; (marko.cvetkovic@rgn.hr)
}

doi: $10.4154 / g c .2017 .07$

Crossref

Article history:

Manuscript received January 31, 2017

Revised manuscript accepted May 05, 2017

Available online June 28, 2017

Keywords: standard deviation trends, marke horizon, correlation, Sava Depression, Pannonian Basin

\begin{abstract}
The regular working method for well log correlation in the Neogene-Quaternary infill of the Croatian Pannonian Basin is based on visual identification of specific motifs that can be observed regionally through the sub-basins or depressions. This method is proven successful through exploration for petroleum accumulations in the aforementioned area but its application is limited outside of the interval of the Upper Miocene sediments and has proven to be subjective. Standard deviation values of well log data from conventional well logs (spontaneous potential, shallow and deep resistivity) were calculated and observed over the entire Neogene-Quaternary well interval for defining new correlation markers which correspond to the old well log marker horizons. Traditionally determined marker horizons did not coincide with those defined by the standard deviation technique. However, new regional horizons were established in the youngest part of the infill, which made more detailed correlation now possible.
\end{abstract}

\section{INTRODUCTION}

Subsurface settings and stratigraphic relations of the Croatian part of the Pannonian Basin (CPBS) have traditionally been divided into formations and members based on research that is ongoing from the 1950s. These strata are generally divided by well log marker horizons, which represent distinctive motifs that can be observed on well log curves, more specifically on the resistivity curves in thick-bedded marls (VRBANAC, 2002). This method is valid when the sedimentary environment is large enough to support the formation of such layers that can be distinguished regionally. In smaller and/or more dynamic environments, a different kind of approach has to be employed to be able

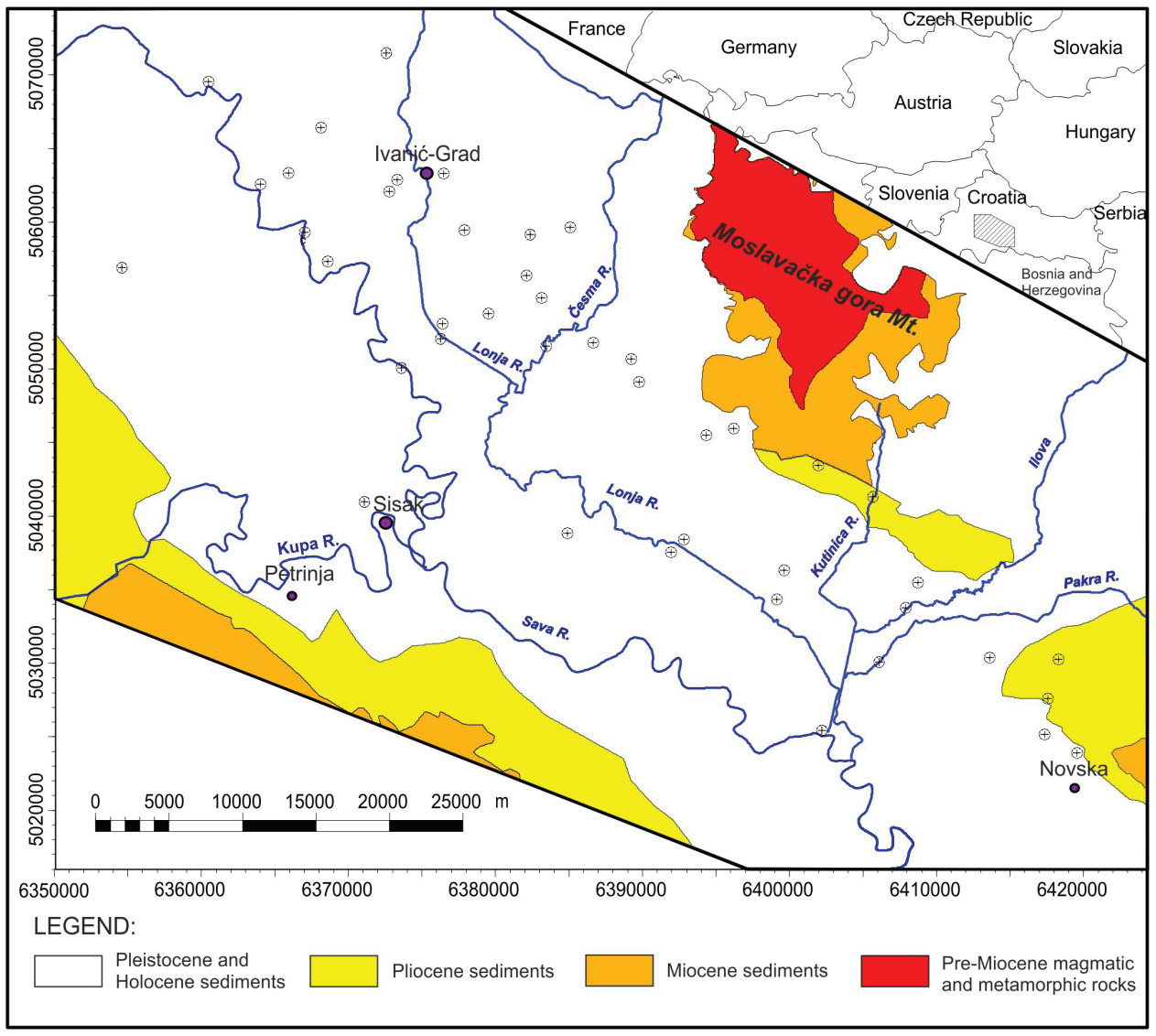

Figure 1. Extent of the exploration area with indicated well locations (from CVETKOVIĆ 2016). 
to regionally correlate deposits in the subsurface. For this purpose, a mathematical approach using cumulative standard deviation curves was tested on well data from the Neogene - Quaternary infill part of the Sava Depression, and Pannonian Basin (Fig. 1). Testing was performed initially on the entire Neogene - Quaternary sediments and later focused on the youngest part - the Pliocene, Pleistocene and Holocene.

\section{GENERAL SUBSURFACE GEOLOGICAL SETTINGS AND PREVIOUS RESEARCH}

Stratigraphic subdivision of the Neogene-Quaternary infill of the CPBS has been performed since the 1950s when the exploration for hydrocarbons began. This subdivision was based on a lithostratigraphical subdivision for each depression in the CPBS. The area of focus for this investigation is the sedimentary infill in the Sava Depression. The Neogene-Quaternary succession in the Sava Depression has been subdivided into six formations with their lithology described in detail in PLETIKAPIĆ (1969), S̆IMON (1973, 1980), VELIĆ et al. (2002); SAFTIĆ et al. (2003), VELIĆ (2007) and which can be generally observed in Fig. 2.

These formations (and members within) are separated by well log marker horizons that are traditionally treated as chronohorizons. A traditional approach for determining the position of the well $\log$ horizon is the selection of the distinctive motifs on well log curves, which could be tracked on adjacent wells. Well log horizons can be conformable, unconformable or can have a dual character; e. g. conformable in the mid part of the depression while unconformable in the marginal areas. Conformable horizons are located within the thick marl layers and it is presumed that these characteristic motifs are the results of minor granulometry changes in marls as a response to environmental influences (VRBANAC, 2002). According to VRBANAC (2002) they not only represent a border between lithostratigraphic units but could also serve as chronohorizons as VRBANAC (2002) presumed that the environmental influences should be simultaneous depression/basin wide. These kind of well log horizons are regionally limited to Late Miocene intervals which had a large accommodation area and a dominant source of clastic materials (VRBANAC, 2002, LUČIĆ et al., 2001, GRIZELJ et al., 2017).

Generally, well log marker horizons should at least be recognizable over a localized area (e.g. the size of a hydrocarbon accumulation) but the most usable ones are those that can be tracked throughout the depression. Various sets of well log curves can be suitable, but the most common that are used for this purpose are the resistivity curves. These form part of the set of conventional electric well log curves that are acquired over the entire well interval unlike other more costly well logging applications that are acquired mostly in limited well intervals, and only in the suspected zone of interest.

As mentioned in the introduction, well log horizons In CPBS have been distinguished in the whole Neogene sequence of sediments with an emphasis on the Upper Miocene clastic infill. Traditionally used regional well log marker horizons that are valid for Sava depression are:

$\mathrm{Tg} / \mathrm{Pt}$ (unconformity) - boundary between Neogene infill and Cenozoic sedimentary rocks $(\mathrm{Pt})$ or magmatic and metamorphic rocks of Mesozoic or Palaeozoic age (Tg).

Rs7 (dual character) - approximate boundary between Middle and Upper Miocene sediments or boundary between Prečec and Prkos formations.
Rs5 (dual character) - boundary between the Lower and Upper Pannonian according to VRBANAC (2002) or the boundary between the Prkos and Ivanić-Grad formations.

Z' (conformable) - boundary between the Upper Pannonian and Lower Pontian (sensu lato as the existence of the Pontian as in Eastern Paratethys is questionable, ĆORIĆ et al., 2009) according to VRBANAC (2002) or between the Ivanić-Grad and Kloštar Ivanić and Široko Polje formations.

$\mathrm{R} \phi$ (conformable) - boundary between the Lower and Upper Pontian (sensu lato) sediments or the Kloštar Ivanić and Široko Polje formations.

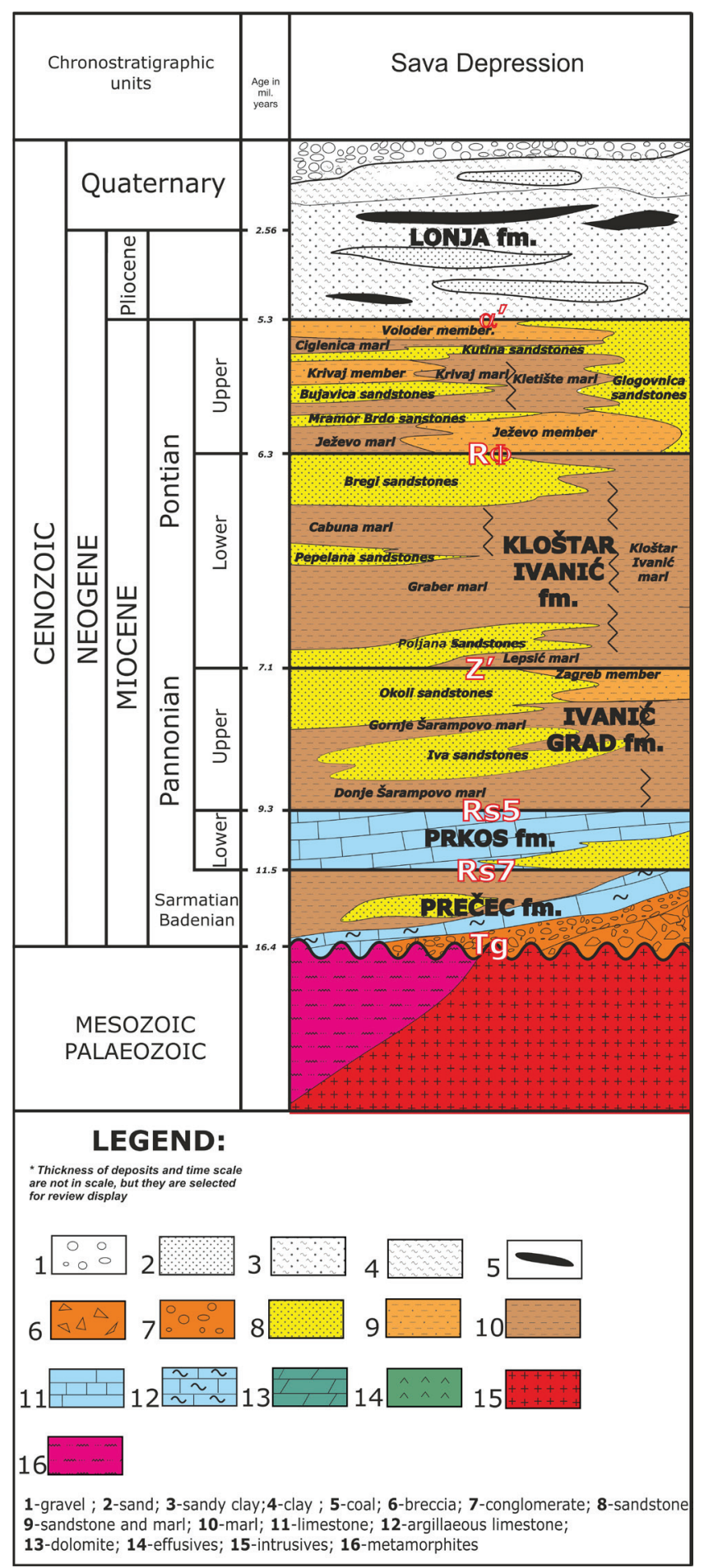

Figure 2. Chronostratigraphic and lithostratigraphic units valid for the Sava Depression (from PODBOJEC \& CVETKOVIĆ, 2016 based on ŠIMON, 1980, ROGL, 1996, VELIĆ, 2002, ĆORIĆ et al., 2009). 
$\alpha$ ' (dual character) - boundary between Miocene and Pliocene sediments according to ŠIMON (1980), VELIĆ (2002), CVETKOVIĆ (2013) or the boundary between the Šroko Polje and Lonja Formations.

A methodology for locating well horizons (visual determination) has been applied from the earliest exploration and has proven to be successful as a large number of hydrocarbon fields and accumulations have been discovered utilizing this approach. This principle is valid worldwide although there were some successful approaches to using geomathematics to determine well log horizons (LUTHI \& BRYANT, 1997; LAPKOVSKY et al., 2015). A downside of the traditional approach is that the method itself is quite subjective and is applicable only in large sedimentary environments where similar conditions existed depression wide. This is a problem observed in more dynamic environments (CVETKOVIĆ, 2013, MANDIC et al., 2015, GRIZELJ, et al., 2017, which existed prior to, and after the Late Miocene).

To overcome these issues, a relatively simple mathematical method was employed for establishing a working method to distinguish horizons in wells in the aforementioned problematic intervals - analysis of trends in curves of standard deviation (CSTDEV). These have been successfully tested on a limited dataset and on a single horizon (CVETKOVIĆ \& MALVIĆ, 2013).

\section{METHODS}

Standard deviation $(\sigma)$ is a measurement of the dispersion of data values in relation to the mean data value (Eq. 1)

whereas:

$$
\sigma=\sqrt{\frac{1}{n_{i}} \sum_{i=1}^{n}\left(x_{i}-\mu\right)^{2}}
$$

$\mathrm{n}$ - number of cases in the observed dataset

$\mu$ - mean value of dataset

$\mathrm{x}_{\mathrm{i}}-\mathrm{i}^{\text {th }}$ member of the dataset

The goal of calculating standard deviation is to determine the amount of change in the environment, which relates to the change in values that can be observed in well log curves.

The value of standard deviation in this case is dependent on two factors. Firstly, well log data dispersion, which directly re- lates to the lithological composition of the rocks (spontaneous potential logs and resistivity logs) and fluid within the rocks (resistivity logs). The second factor is the radius (or window) of the observed interval or resolution of standard deviation sampling. As the first factor is constant, the influence of the radius interval was tested for three cases - one metre, two metre, and four metres. The centre point interval is the data point for observation of standard deviation (STDEV, Fig. 3). All conventional electric well $\log ($ E-log) curves were initially subjected to STDEV analysis (normalized spontaneous potential, SPN; shallow resistivity, R16 and deep resistivity, R64). Resistivity curves, in general, did not prove to be appropriate for STDEV analysis (CVETKOVIĆ \& MALVIĆ, 2013); so the focus was on the SPN values.

Numerically, when observing standard deviation, the values less than 1 represent homogenous impermeable intervals (eg. marls and shales) between 1 and 5 for dominantly sandstone intervals, and more than 4 for thin layered marl-sandstone successions. For further emphasizing the STDEV values for differentiating monotonous marl intervals from dynamic environments, the standard deviation value was squared. In this way, the numerical value of STDEV for marls being less than 1 was squared (STDEV_R2) and smaller in reference to STDEV values that were initially greater than 1. Results of plotting these STDEV and STDEV_R2 values over a well interval shows the distribution of the data dispersion. The peak values can be used for defining lithological boundaries as they fall on the mid-point of the curve of inflexion. In this way, defining lithological boundaries is a less subjective process and can serve as a benchmark for training purposes as the correct procedure requires the boundary to be put on the mid-point of the inflexion of the curve (BASSIOUNI, 1994, BAKER et al., 2015).

Values of standard deviation on a specific point as shown in Fig. 4 represent only the dynamics of the environment in a single point, plotted over an entire well interval, but little information is revealed about the general dynamics. Cumulative value curves of selected data have been previously used to depict trends in the subsurface, e.g. cumulative dip values were plotted along the depth axis of a well from dipmeter values (BENGSTON, 1981; HURLEY, 1994; VELIĆ et al., 2009). In those instances the cumulative value curves show a general trend in change of dip in-

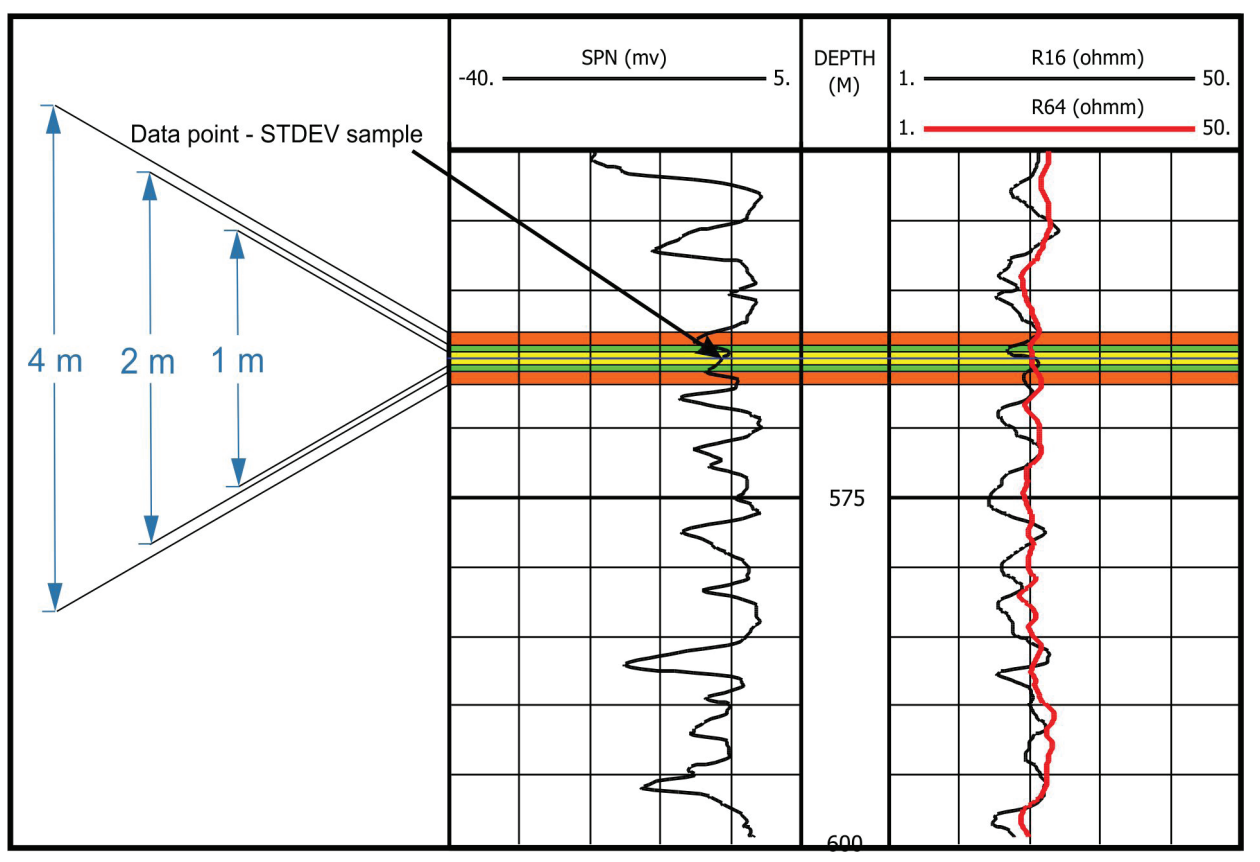

Figure 3. Representation of the interval used for calculated STDEV values in the case of 1,2 and 4 metres. 


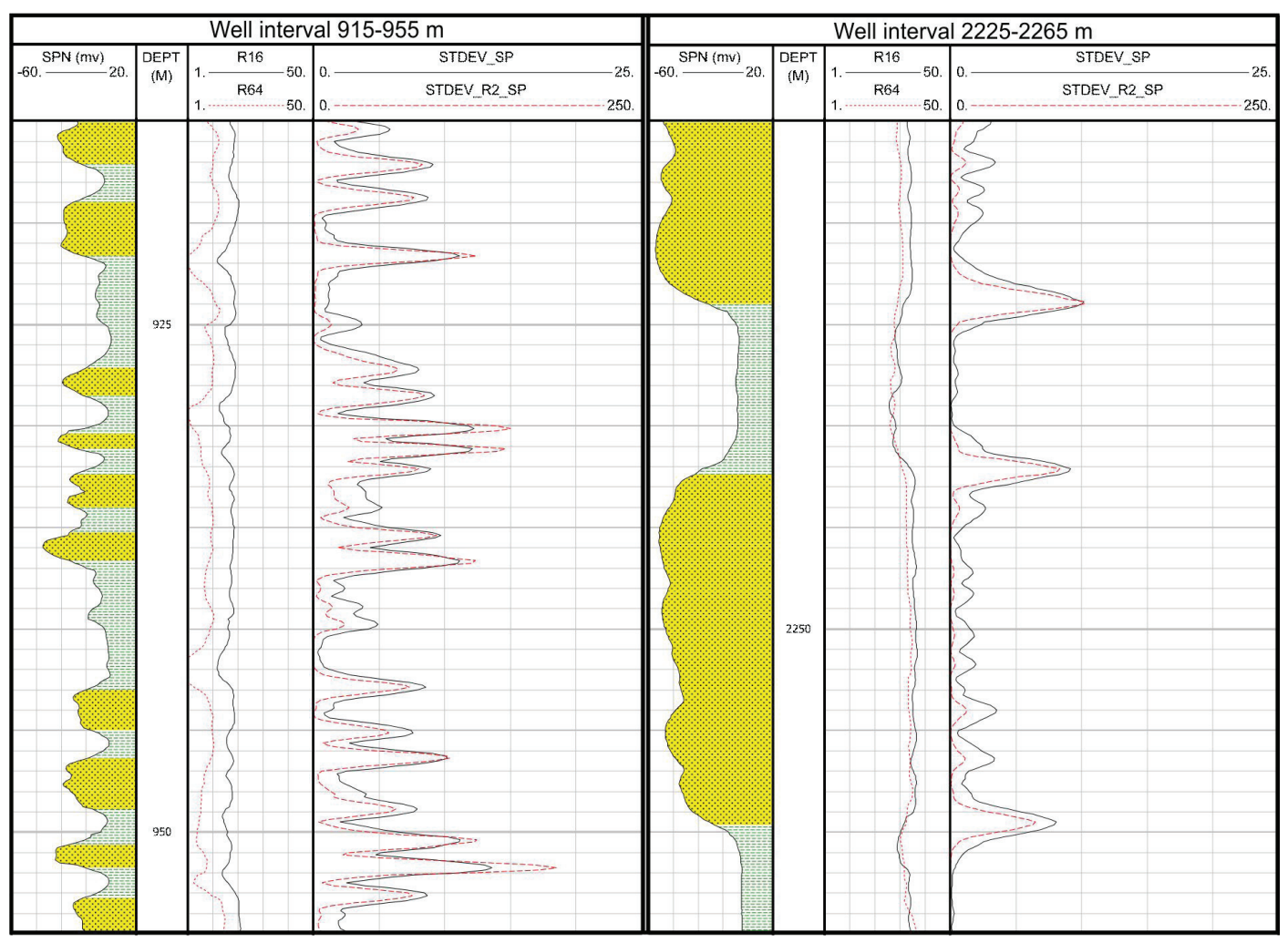

Figure 4. STDEV and STDEV_R2 values plotted against a thin-layered section (left) and a thick-layered section (right).

clination which could be related to the prevailing tectonic regime. A similar approach was performed with STDEV values when plotted as a cumulative standard deviation curve (CSTDEV). Initial testing was performed for defining the optimal resolution of STDEV value to be plotted on a CSTDEV curve. Testing was performed for one, two and four metre windows. The applicability of each resolution window was tested by comparing it with a well $\log$ horizon which should indicate a great change in the sedimentary environment when the large lake system was significantly reduced and marsh environments occurred on a larger scale, e.g. in the case of $\alpha^{\prime}$ (CVETKOVIĆ, 2013, MANDIC et al., 2015). Although curves of all three windows showed a break pattern, the one metre version was most precise when compared to the data acquired from the initial well log horizon database (CVETKOVIĆ \& MALVIĆ, 2013).

As defining trends based on CSTDEV curves relies on visual determination, a square value of standard deviation was also plotted as a cumulative curve (CSTDEV_R2). In this way, curves represent the general environmental dynamics where low increments of cumulative data value increases represent a small change in the environment and a high increment suggests a dynamic environment. Squared values emphasize the low and high changes in the environment to an even greater extent.

As a final step curves have to be normalized for the purpose of easier visualization. In contrast to plotting the CSTDEV and CSTDEV R2 values which can differ significantly from well to well, values were plotted as a percentage of the maximum value on the axis (Fig. 5). In this way, cross-correlation should prove more reliable as values of spontaneous potential for lithology can differ from well to well based on well logging conditions.

\section{RESULTS}

Analysis of CSTDEV and CSTDEV_R2 curves was performed on 43 wells in the Sava Depression (Fig. 1). The first part of the

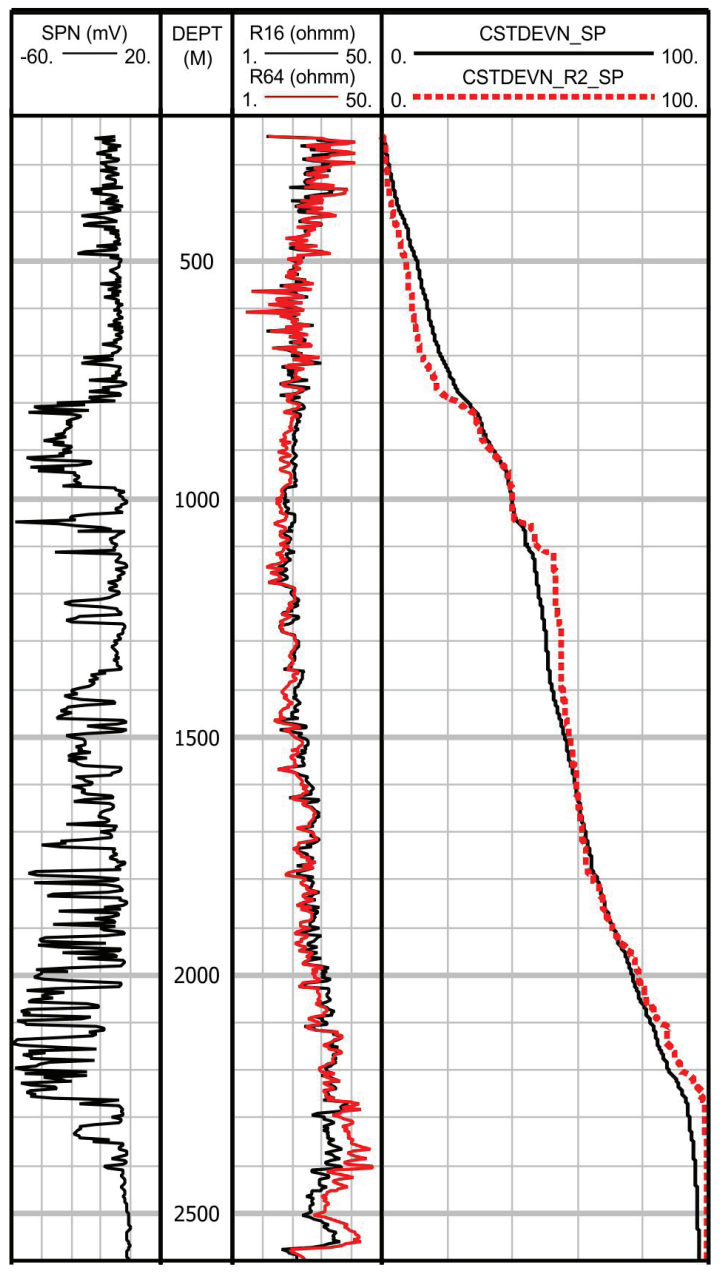

Figure 5. Results of plotting cumulative standard deviation value curves of normal (CSTDEVN) and squared (CSTDEVN_R2) values of SP for the entire interval of Well 1. 


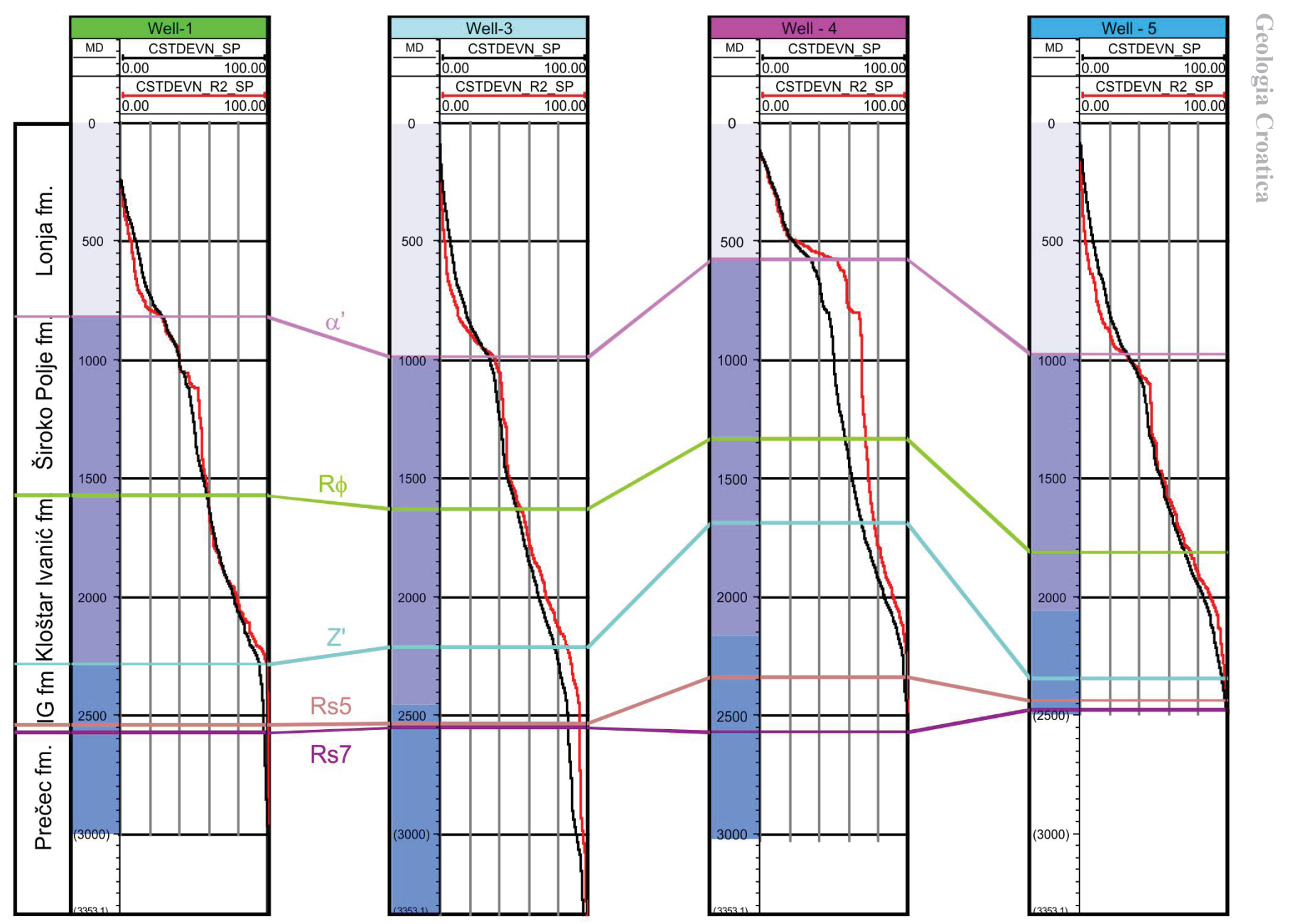

$1^{\text {st }}$ CSTDEV interval

$2^{\text {nd }}$ CSTDEV interval

$3^{\text {rd }}$ CSTDEV interval

Figure 6. Relation of well log horizons determined by traditional methods and general trends by CSTDEV curves.

analysis concerned the entire Neogene-Quaternary infill where regional well log marker horizons were plotted against calculated curves. Several breaks in curve trends were present, but two distinctive ones can be correlated throughout the Depression. Unfortunately, only one of these breaks can be related to existing well $\log$ horizons, namely marker horizon $\alpha$ ' (boundary of the $2^{\text {nd }}$ and $3^{\text {rd }}$ intervals, Fig. 6).

The $1^{\text {st }}$ interval defined by this break generally represents the Prečec and Prkos formations but can extend to even the Kloštar Ivanić formation (Fig. 6, Well 6). In general, sandstone layers are either thicker in this interval or absent, thus resulting in low STDEV values and a low increment CSTDEV trend.

A $2^{\text {nd }}$ interval relates to a clastic infill of the Ivanić-Grad, Kloštar Ivanić and Široko Polje formations. Sandstone layers are generally thicker than $10 \mathrm{~m}$. Several trends can be observed within this interval but those do not follow any of the well log marker horizons that are traditionally in use. Unfortunately, seismic cross sections were not available for testing the possibility of correlation in this interval.

The $3^{\text {rd }}$ interval belongs to thin layered $(<5 \mathrm{~m})$ clays and sands which are poorly sorted. Frequent lithology changes resulted in steep gradients in the CSTDEV curves. The basal boundary of the interval is well defined and marked by a break in the CSTDEV curve which coincides with regional well log marker horizon $\alpha$.
The second part of the analysis focused only on sediments of the Lonja formation ( $3^{\text {rd }}$ interval; approximate age interval - Pliocene, Pleistocene and Holocene). Three distinctive trends were observed on CSTDEV curves in a confined interval (Fig. 7).

These breaks could be tracked through the entire research area. The CSTDEV_R2 curve showed too much sensitivity to change in the SPN values which resulted in many trends that could not be correlated on a larger scale. Thus, for further research, a less sensitive parameter for observation in the data trend could be employed such as the median absolute deviation (MAD) as in FEDOR et al. (2002).

These trend breaks served as boundaries that define members in the Lonja formation on which the infill of the youngest formation in the Sava Depression was subdivided and subsequently mapped (CVETKOVIĆ, 2013). Furthermore, the position of $\alpha^{\prime}$ horizon was adjusted on several positions based on CSTDEV curves to reflect the change in lithology.

\section{CONCLUSIONS}

Observation of standard deviation values and trends on a cumulative curve plot has proven to be of significant value. Plotting STDEV values against E-log curves during the initial part of the lithological analysis can help the interpretation in positioning the boundaries between different lithologies as maximum values fall onto a mid-point of the curve inflexion. In this way, an objective 


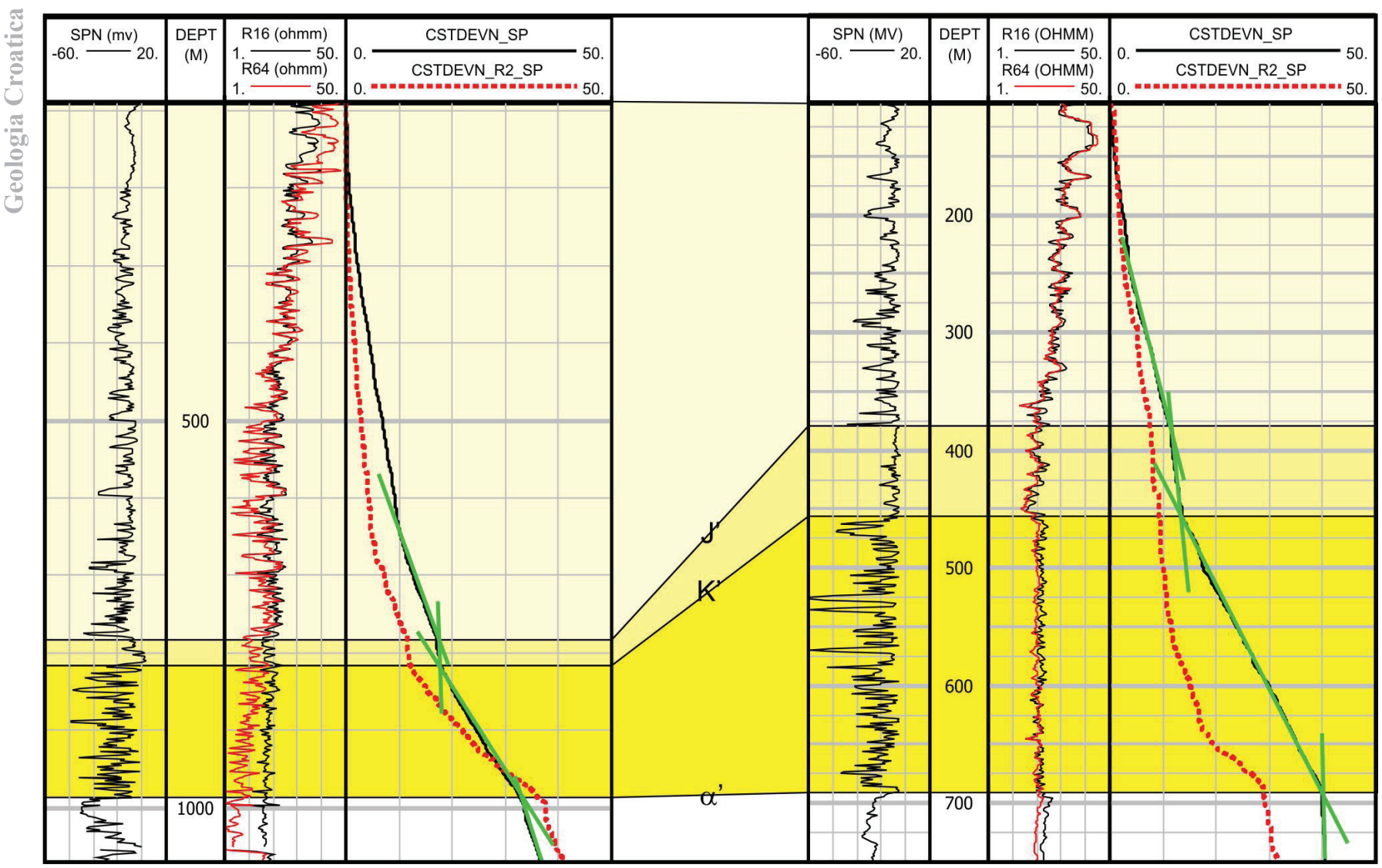

Figure 7. Positioning well log horizons ( $J^{\prime}$ and $K^{\prime}$ ) within the Lonja formation and $\alpha^{\prime}$ based on trend line (green) intersections.

parameter can be introduced in well log analysis rather than putting the approximate location based on experience or using cutoff values for lithology, which can differ due to the nature of acquiring the well $\log$ (e.g. water composition and salinity of the formation waters in contrast to mud properties).

Observing trends and break points in CSTDEV and CSTDEV_R2 curves did not show relationships with existing well log marker horizons, which makes their applicability in the Upper Miocene sediments questionable. This should be further tested against seismic stratigraphy to be either dismissed or further investigated.

A distinctive break is present at the base of the Lonja formation on both CSTDEV curves, which can be related to the $\alpha$ ' well $\log$ marker horizon. Furthermore, two distinctive breaks within the Lonja formation can be located on the CSTDEV curve that can be tracked throughout the depression. The CSTDEV_R2 curve in this instance showed too many breaks in trends (aka noise) and as a result, the two well marker horizons, which could be clearly seen with the CSTDEV approach, were obscured. This additionally raises the question of testing statistical analysis which are less sensitive to extreme values in the dataset (e.g. MAD analysis) as a path for further analysis.

Based on the presented data, the CSTDEV curves proved to be valuable for correlating the well logs in intervals within thinlayered successions in which regional well log marker horizons are absent due to the more restricted depositional environments.

\section{ACKNOWLEDGMENT}

The author would like to thank Lloyd's Register for donating academic licenses of Interactive Petrophysics and Schlumberger for donating academic licenses of Petrel to University of Zagreb,
Faculty of Mining, Geology and Petroleum Engineering without which this material would not be possible to be produced in its full extent.

The publication process is supported by the Development Fund of the Faculty of Mining, Geology and Petroleum Engineering, University of Zagreb.

\section{REFERENCES}

BAKER, R.O., YARRANTON, H.W. \& JENSEN, J.L. (2015): Openhole Well Logs-Log Interpretation Basics.- In: YARRANTON, H.W., BAKER, R.O. \& JENSEN, J.L. (eds.): Practical Reservoir Engineering and Characterization, Elsevier, 534, 297-343. doi: 10.1016/B978-0-12-801811-8.00009-2

BASSIOUNI, Z. (1994): Theory, Measurement, and Interpretation of Well Logs.- Society of Petroleum Engineers, Richardson, 372 p.

BENGTSON, C.A. (1981): Statistical Curvature Analysis Techniques for Structural Interpretation of Dipmeter Data.-AAPG Bull., 65/2, 312-332.

CVETKOVIĆ, M. (2013): Naftnogeološki potencijal i litostratigrafska razradba trećega neogensko-kvartarnoga megaciklusa u Savskoj depresiji [Lithostratigraphic units of the third Neogene-Quarternary megacycle in the Sava Depression and their petroleum potential - in Croatian with an English Abstract].- Unpubl. PhD Thesis, University of Zagreb, Faculty of Mining, Geology and Petroleum Engineering, Zagreb, $175 \mathrm{p}$.

CVETKOVIĆ, M. (2016): Modelling of maturation, expulsion and accumulation of bacterial methane within Ravneš Member (Pliocene age), Croatia onshore.- Open Geosci., 8, 5-13. doi: 10.1515/geo-2016-0002

CVETKOVIĆ, M. \& MALVIĆ, T. (2013): Defining electro-log markers in poorly consolidated, heterogeneous clastic sediments using standard deviation data trends an example from the Sava Depression, Pannonian Basin System.- In: HORVÁTH, J., WÁGENHOFFER, A., GEIGER, J., CVETKOVIĆ, M. \& MALVIĆ, T. (eds.): 16th Hungarian \& 5th Croatian and Hungarian congress abstract and program book. Hungarian Geology Society \& INA Oil Industry Plc., Szeged. doi: 10.13140/2.1.3191.0409

ĆORIĆ, S., PAVELIĆ, D., RÖGL, F., MANDIC, O., VRABAC, S., AVANIĆ, R., JERKOVIĆ, L., \& VRANJKOVIĆ, A. (2009): Revised Middle Miocene datum for initial marine flooding of North Croatian Basins (Pannonian Basin System, Central Paratethys).- Geol. Croat., 62/1, 31-43. doi: 10.4154/GC.2009.03 
GRIZELJ, A., PEH, Z., TIBLJAŠ, D., KOVAČIĆ, M. \& KUREČIĆ, T. (2017): Mineralogical and geochemical characteristics of Miocene politic sedimentary rocks from the south-western part of the Pannonian Basin System (Croatia): Implications for provenance studies.- Geoscience Frontiers, 8, 65-80. doi: 10.1016/j.gsf.2015.11.009

FERENC, F., FEGYCERNEKI, S., HÁMÓR-VIDO, M. \& LÖVEI, J. (2001): A Possible Way of Statistical Analysis at Small Sample Size.- In: LAKATOS, I. (eds.): Novelties in Enhanced Oil and Gas Recovery. Akadémiai Kiadó, Budapest, 1-14.

HERNITZ, Z., VELIĆ, J., KRANJEC, V. \& NAJDENOVSKI, J. (1980): Prikaz diferencijalnih i maloamplitudnih struktura s primjerima iz Savske potoline (Panonski bazen) [Diferential and small amplitude structures examples from Sava Depression (Pannonian Basin) - in Croatian].- Nafta, 7-8, 399-409.

HURLEY, N.F. (1994): Recognition of Faults, Unconformities and Sequence Boundaries using Cumulative Dip Plots.-AAPG Bull., 78/8, 1173-1185.

LAPKOVSKY, V.V., ISTOMIN, A.V., KONTOROVICH, V.A. \& BERDOV, V.A. (2015): Correlation of well logs as a multidimensional optimization problem.Russ. Geol. Geophys., 56/3, 489-492. doi: 10.1016/j.rgg.2015.02.009

LUTHI, S.M. \& BRYANT, D. (1997): Well-Log Correlation Using a Back-Propagation Neural Network.- Math. Geol., 29/3, 413-425. doi: 10.1007/BF02769643

MANDIĆ, O., KUREČIĆ, T., NEUBAUER, T.A. \& HARZHAUSER, M. (2015): Stratigraphic and palaeogeographic significance of lacustrine molluscs from the Pliocene Viviparus beds in central Croatia.- Geol. Croat., 68/3, 179-207. doi:10.4154/ gc.2015.15

PLETIKAPIĆ, Z. (1969): Stratigrafija, paleogeografija i naftoplinonosnost Ivanić-Grad formacije na obodu Moslavačkog masiva [Stratigraphy, palaeogeography and petroleum geology of Ivanic-Grad formation on the edge of Moslavačka gora Mt. in Croatian].- Unpubl. PhD Thesis, University of Zagreb, Faculty of Mining, Geology and Petroleum Engineering, Zagreb, 71 p.

PODBOJEC, M. \& CVETKOVIĆ, M. (2016): Preliminary estimate of CO2 storage capacity by petrophysical modelling in Upper Miocene Poljana Sandstones in the western part of the Sava Depression.- The Mining-Geology-Petroleum Engineering Bulletin, 31/1, 31-44. doi: 10.17794/rgn.2016.1.3

RÖGL, F. (1996): Stratigraphic Correlation of the Paratethys Oligocene and Miocene. - Mitteilungen Ges. Geol. Bergbaustudenten Österreich, 41, 65-73.

SAFTIĆ, B., VELIĆ, J., SZTANÓ, O., JUHÁSZ, G. \& IVKOVIĆ, Ž. (2003): Tertiary subsurface facies, source rocks and hydrocarbon reservoirs in the SW part of the Pannonian Basin (northern Croatia and south-western Hungary).- Geol. Croat., 56/1, 101-122. doi: 10.4154/232

ŠIMON, J. (1973): O nekim rezultatima regionalne korelacije litostratigrafskih jedinica u jugozapadnom području Panonskog bazena [Results of regional well log correlation of lithostratigraphic units in Southwestern part of Pannonian Basin - in Croatian].- Nafta, 24/12, 623-630.

ŠIMON, J. (1980): Prilog stratigrafiji u taložnom sustavu pješčanih rezervoara Savagrupe naslaga mlađeg tercijara u Panonskom bazenu sjeverne Hrvatske [An Addition to the stratigraphy of the sedimentary system of sandstone reservoirs of Sava group in younger Tertiary in Pannonian Basin of the Northern Croatia area - in Croatian].- Unpubl. PhD Thesis, University of Zagreb, Faculty of Mining, Geology and Petroleum Engineering, Zagreb, 66 p.

VELIĆ, J., WEISSER, M., SAFTIĆ, B., VRBANAC, B. \& IVKOVIĆ, Ž. (2002): Petroleum-geological characteristics and exploration level of the three Neogene depositional megacycles in the Croatian part of the Pannonian basin.- Nafta, 53/6-7, 239-249.

VELIĆ, J., MALVIĆ, T., CVETKOVIĆ, M. \& BOŠNJAK, M. (2012): Statistical Analysis of Dipmeter Logs from Exploration Wells in the Drava Depression, Northern Croatia.Journal of Petroleum Geology, 35/4,343-356. doi: 10.1111/j.1747-5457.2012.00534.x

VRBANAC, B. (2002). Facies and facies architecture of the Ivanić-Grad Formation (Late Pannonian)-Sava Depression, NW Croatia.- Geol. Croat., 55/1, 57-77. doi: 10.4154/GC.2002.06 